\title{
EXPERIMENTAL INVESTIGATION OF SPRINGBACK OF LOCALLY HEATED ADVANCED-HIGH STRENGTH STEELS
}

\author{
Omer Eyercioglu ${ }^{*} \bowtie(D)$, Sevket Alacaci ${ }^{1}$, Mehmet Aladag 1 \\ ${ }^{* 1}$ Department of Mechanical Engineering, Gaziantep University, Gaziantep, Turkey
}

DOI: https://doi.org/10.29121/granthaalayah.v9.i3.2021.3811

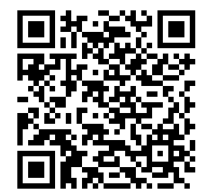

Article Type: Research Article

Article Citation: Omer Eyercioglu, Sevket Alacaci, and Mehmet Aladag. (2021). EXPERIMENTAL INVESTIGATION OF SPRINGBACK OF LOCALLY HEATED ADVANCEDHIGH STRENGTH STEELS.

International Journal of Research GRANTHAALAYAH, 9(3), 269-277. https://doi.org/10.29121/granthaa layah.v9.i3.2021.3811

Received Date: 17 March 2021

Accepted Date: 31 March 2021

Keywords:

Springback

V-Bending

Local Heating

AHSS

Docol 1500M

\section{ABSTRACT}

Sheet metal bending is one of the important metals forming processes at ambient temperature. The usage of high-strength steel is one of the stronger materials for the construction of components in the automotive industries. However, for complex shapes, cold forming is not always sufficient, and heating the workpiece plays a major role in manufacturing these shapes. Bendability may increase with increasing forming temperature and currently, hot forming of advanced high strength steels (AHSS) is becoming more attractive. While hot forming of AHSS is beneficial for high formability, subsequent quenching is required to maintain final strength. This procedure extends the production time. In this study, temperature gradients, bending loads, and springback after Vbending were investigated. The experimental study was carried out on a 2 mm thick Docol $1500 \mathrm{M}$ steel at various temperatures by using a speedcontrolled servo press machine. The bending regions of the specimens were locally heated to $200,300,400,500$, and $600 \mathrm{oC}$ by using a highfrequency induction heating device. The results show that; punch loads were significantly lowered with increasing the local heating temperature during bending. There were no cracks observed on the specimens. The amount of spring back is decreasing with the bending temperature and around $500 \mathrm{oC}$ almost no springback was measured. Negative spring back was observed for the bending temperatures higher than $500 \mathrm{oC}$.

\section{INTRODUCTION}

Advance High Strength Materials (AHSS) are widely preferred for the fabrication and development of automotive industry components. There are also many industrial products where reduced weight and increase product durability can be achieved by utilizing advanced high-strength steel in their designs. In metal forming industrial applications, manufacturers need to use products with light weighted, high strength, and better impact resistance materials. The long-term life cycle of material plays a major role in the selection of AHSS materials. Especially with using of AHSS materials in the automotive industry, a lower emission level is achieved by reducing vehicle weight. The strength of workpiece material has also a major parameter. For similar grades, cold-rolled metal can be stronger than hot-rolled metal because of what's called work hardening. Hot forming application is a temperature \& time-dependent process. Parts produced by hot forming are characterized by high strength, complex shapes, and reduced spring-back effects. Optimal material behavior is achieved through the structural transformation of austenite into martensite. In metal forming, compressive force is locally applied on the workpiece through a forming tool by means of die and punch combination. This force causes to generates high contact pressures

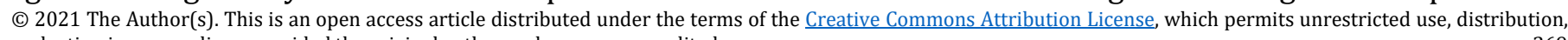
and reproduction in any medium, provided the original author and source are credited. 
at the interface boundary between workpiece and tool and finally, the workpiece is subject to deformation to deliver the required shape and surface of the product. During the deformation process, higher shearing stresses are generated with an increase in local temperature due to arisen of frictional effect and plastic strain behaviors.

The AHSS family is composed of Dual-Phase (DP), Complex-Phase (CP), Ferritic-Bainitic (FB), Martensitic (MS or MART), Transformation-Induced Plasticity (TRIP), Hot-Formed (HF), and Twinning-Induced Plasticity (TWIP) steels. These 1st and 2nd Generation AHSS grades are uniquely qualified to meet the functional requirements of certain components. The tensile strength to percent elongation of AHSS grades are shown in Figure 1. Formability difficulties of high-strength materials without heat treatment is one of the main bottlenecks to fabricate complicated parts. However, heat application on the whole material surface is caused reduced strength. Therefore, local heating may be applied to the bending line in order to prevent strength reductions. The effects of temperature gradient and strain rates on the locally heated sheets have been interested and studied by researchers.

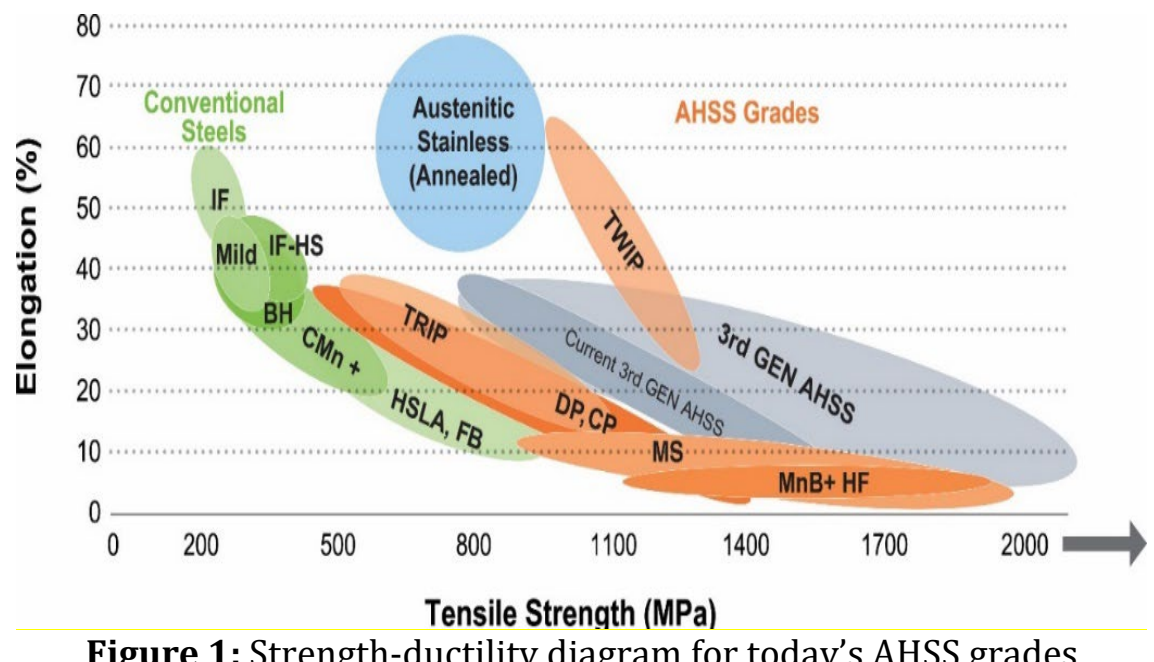

Figure 1: Strength-ductility diagram for today's AHSS grades

Due to its lightweight, high specific strength, dual-phased (DP) steel materials have been widely used for structural components in the automotive industry [1]. DP steel has high yielding and fracture behaviors during uniaxial tension. However, DP martensitic steels have high spring back effects and low elongation [2]. Since high spring-back is an obstacle to the widespread use of light metals, many studies have been done to reduce spring-back by increasing the temperature when punch load applied.

Lee et al. proposed local heating by using near-infrared rays to reduce the spring back of high-strength steels. V-bending was conducted on DP steel sheets. Their results showed that shape accuracy and hardness after bending with NIR local heating have advantages over furnace heating [3]. The free mechanism of spring back in hot stamping of UHS steel parts was experimented with by the mechanical, thermal, and transformation viewpoints [4]. One of the major obstacles was that a large amount of spring back has been encountered after hot and warm sheet forming. However, the reduction of spring back is markedly observed during forming at a critical temperature higher than $750 \mathrm{~K}$ [5]. In another study was done by Lee et al. to reach a prediction of the combined effects of kinetics transformation and thermal-mechanical behavior during mechanical forming at high temperatures and subsequent cooling. They showed that a significant amount of spring-back is predicted only when using conventional plasticity with volumetric stress due to lower yield stress and phase difference at high temperatures [6].

Weisheit carried out local laser heat treatment of ultra-high strength steels to improve formability and the results show that laser heat treatment has a great impact on improving the formability of UHS steels [7]. Linus studied warm forming with localized in-tool induction heating and show that the formability of high-strength steels can be improved significantly [8]. In order to obtain the effect of temperature on spring back and hardness of sheet metal parts, some hot bending experiments were carried out by non-isothermal bending method using tool temperatures ranging from $25^{\circ} \mathrm{C}$ to $400^{\circ} \mathrm{C}$. Meanwhile, isothermal bending experiments were conducted for comparison at $200^{\circ} \mathrm{C}$ and $300^{\circ} \mathrm{C}$, keeping the temperatures of the blank and the dies the same. The results showed that when the cavity temperature was the same during bending, the non-isothermal bend members had about $10 \%$ less spring-back than the isothermal bend members [9]. 
In another study done by Chen, both the experimental approach and finite element analysis have been used to examine the amount of spring-back that occurs in shaping a front bumper interior made of advanced high-strength steel. Different die designs have been used to ensure that the size of the automotive part conforms to the design specification and to adjust the amount of spring-back [10].

In this study, temperature gradients, bending loads, and spring back after V-bending were investigated. The experimental study was carried out on a $2 \mathrm{~mm}$ thick Docol $1500 \mathrm{M}$ steel at various temperatures by using a speedcontrolled servo press machine. The bending regions of the specimens were locally heated to $200,300,400,500$, and $600^{\circ} \mathrm{C}$ by using a high-frequency induction heating device. The temperature gradients, punch loads, and spring back was recorded.

\section{MATERIALS AND METHODS}

\subsection{MATERIAL}

In this experimental study, a $2 \mathrm{~mm}$ thick Docol $1500 \mathrm{M}$ quality sheet was used (see Table 1). The specimens in dimensions of $30 \times 80 \mathrm{~mm}$ were sheared by a cold shearing machine. The chemical composition and mechanical properties of the Docol 1500M are given in Table 2 and Table 3, respectively.

Table 1: Material Definition parameters

\begin{tabular}{|c|c|}
\hline Parameters & Value \\
\hline Material & DOCOL 1500 M \\
\hline Steel Grade & Docol CR 1220Y 1500 TMS \\
\hline Roll Forming Type & UC-Cold Rolling \\
\hline Thickness Range & $0.5 \mathrm{~mm}-2.1 \mathrm{~mm}$ \\
\hline Dimension Range & width up to $1527 \mathrm{~mm}$. \\
\hline Tolerances & EN10131. \\
\hline
\end{tabular}

Table 2: Chemical composition (max\%).

\begin{tabular}{|c|c|c|c|c|c|c|c|c|c|}
\hline $\mathrm{C}$ & $\mathrm{Si}$ & $\mathrm{Mn} \%$ & $\mathrm{P}$ & $\mathrm{S}$ & $\mathrm{Al}$ & $\mathrm{Nb}+\mathrm{Ti} \mathrm{Cr}+\mathrm{Mo}$ & $\mathrm{Cu}$ & $\mathrm{B}$ \\
\hline 0.28 & 0.40 & 1.30 & 0.02 & 0.01 & 0.01 & 0.10 & 1.00 & 0.20 & 0.01 \\
& & & & & 5 & & & & \\
\hline
\end{tabular}

Table 3: Mechanical Properties

\begin{tabular}{|c|c|}
\hline Parameters & Value \\
\hline Test Direction & (RD) Rolling Direction \\
\hline Yield Strength Rp0.2 & $1198 \mathrm{MPa}$ \\
\hline Tensile Strength Rm & $1590 \mathrm{MPa}$ \\
\hline Elongation A80 & $3 \%(\mathrm{~min})$ \\
\hline BH2 & $30 \mathrm{MPa}(\mathrm{min})$ \\
\hline Inner Bending Radius & $4.0 \times \mathrm{t}$ for bending angle- 90 \\
\hline
\end{tabular}

\subsection{EXPERIMENTAL SET UP}

A photograph of the whole setup is given in Figure 2. The setup includes a prototype servo press, a highfrequency induction heater, and measurement devices such as a thermal camera, infrared gun, and radius gauges. 


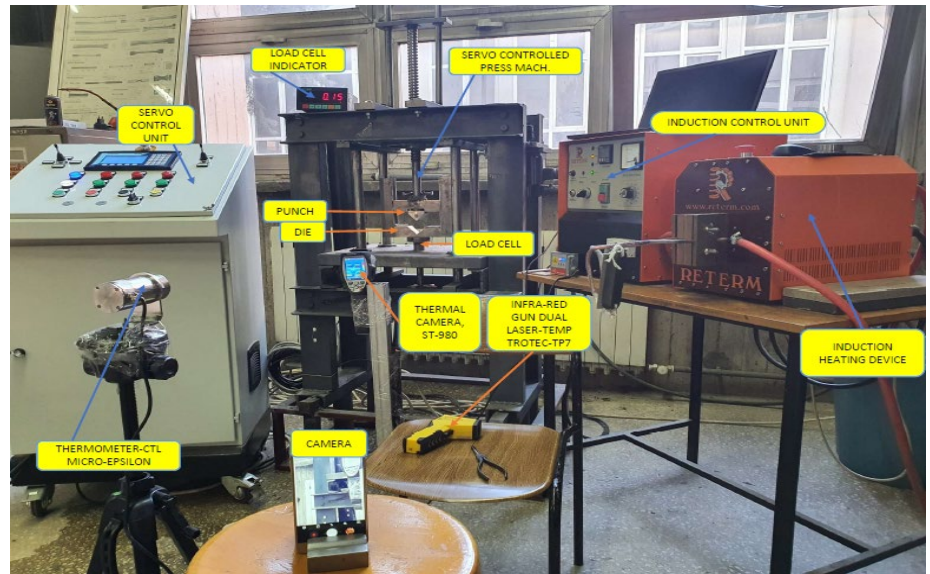

Figure 2: Equipment for Experimental Studies

The die and punch set made from AISI 4140 alloy steel as per ASTM A29/A29M Steel Grade Standard was designed for a 90 -degree $V$-bending shape with a punch radius of $6 \mathrm{~mm}$. The geometric specifications of the die and the punch set are given in Figure 3.

The servomotor-controlled press has two movable punches (top and bottom) which are driven by two separate servo motors. In this study, the lower punch is fixed and the V-bending die set on the press bed. The maximum capacity of the press is 2 metric tons and it is equipped with load cells and linear encoders to plot load-stroke diagram.

An RT-380M50 type high-frequency induction heater was used to heat the specimens and a special flat coil was used to locally heating the middle zone of the specimens. The technical specifications of the induction heater are given below (Table 4).

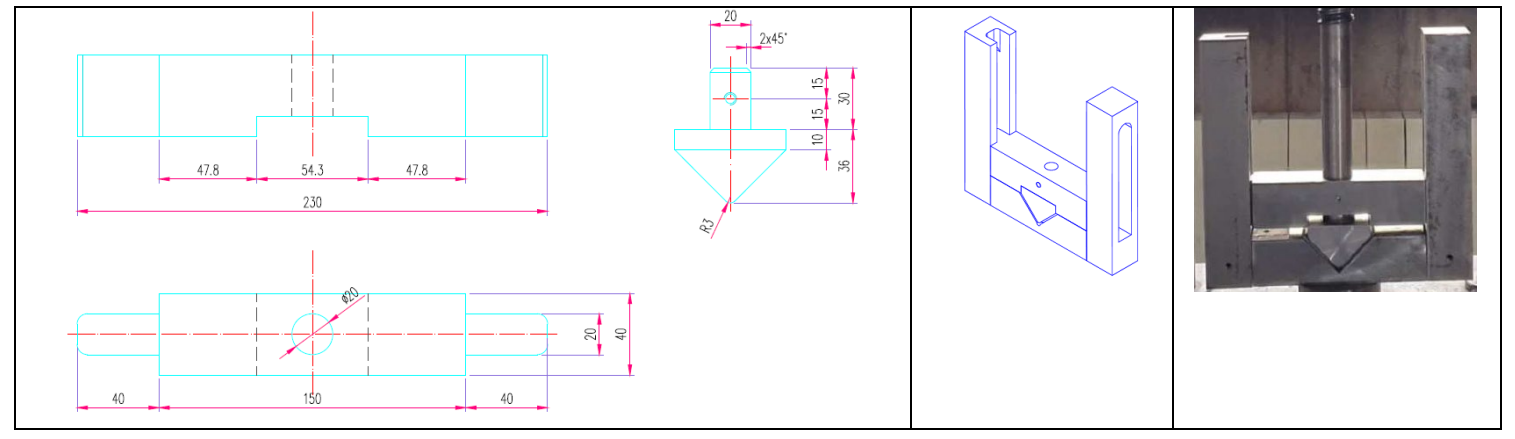

Figure 3: Die and punch set drawing and photo

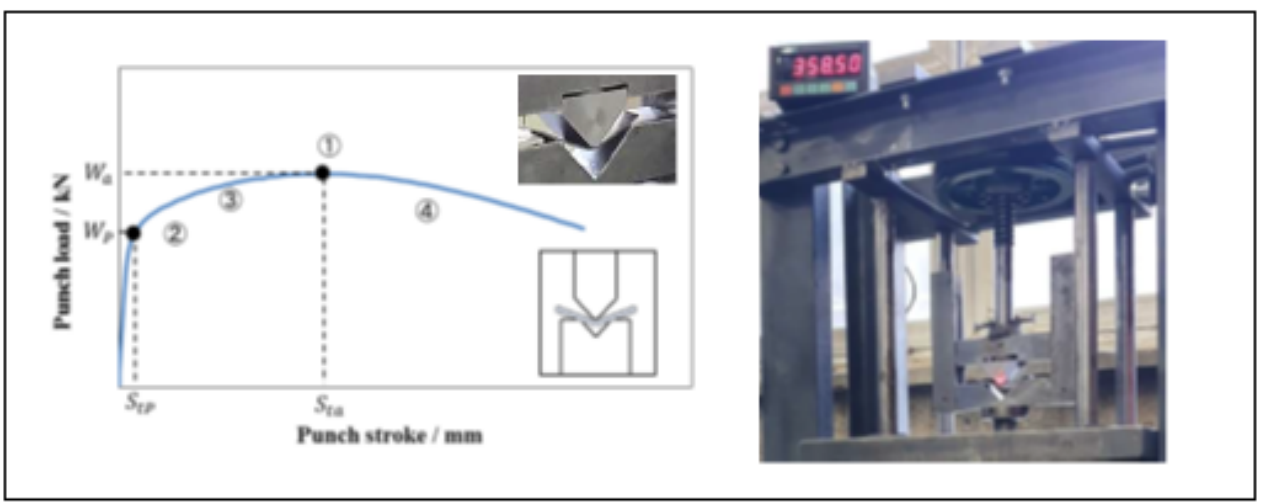

Figure 4: (1) Maximum Load (2) load at elastic limit, (3) load between the elastic limit and the max. load, (4) load after the maximum load point. 
Table 4: Technical Properties of Induction Heating Machine

\begin{tabular}{|c|c|}
\hline Specifications & Magnitudes \\
\hline Model, type & RT-380M50 \\
\hline Power & $50 \mathrm{Kw}$. \\
\hline Capacity & $75 \mathrm{Kg} / \mathrm{hr}$. \\
\hline Current & $380 \mathrm{Volt}-100 \mathrm{Amp}$. \\
\hline Frequency Range & $1.7-12 \mathrm{Khz}$. \\
\hline
\end{tabular}

A manual type dual laser-temp Trotec TP7 infrared temperature measurement gun, a thermo-meter CTL model M3H2 thermometer, and a thermal camera (Tesco 875-2i) were used for temperature measurement and the thermal images of the process. The captured thermal images were analyzed using Tesco IRSoft software.

The dimensions of the final geometry of the specimens (bend radius, thickness, and bend angle) were measured by using a Kemco 3D coordinate measurement machine (CMM).

\subsection{EXPERIMENTAL STUDY AND PROCEDURE}

Six sets of the specimens have been bent by using a punch that has a $6 \mathrm{~mm}$ tip radius (see Figure 5). Three specimens were bent in each set, in order to repeatability the results. Firstly, cold bending was done at room temperature. Then, bend applications were performed for $200,300,400,500$, and $600^{\circ} \mathrm{C}$. The mid-line of specimens was heated locally by using the induction heater. The heated specimens were then transferred quickly to the press and a V-bending process was carried out simultaneously. The stroke is controlled by the servo drive of the press. The punch load with respect to stroke and temperature with respect to time were recorded. The final forms of the specimens were measured by a 3D coordinate measuring machine and the deviations of the bend angle from 90 degrees (spring back) were calculated.

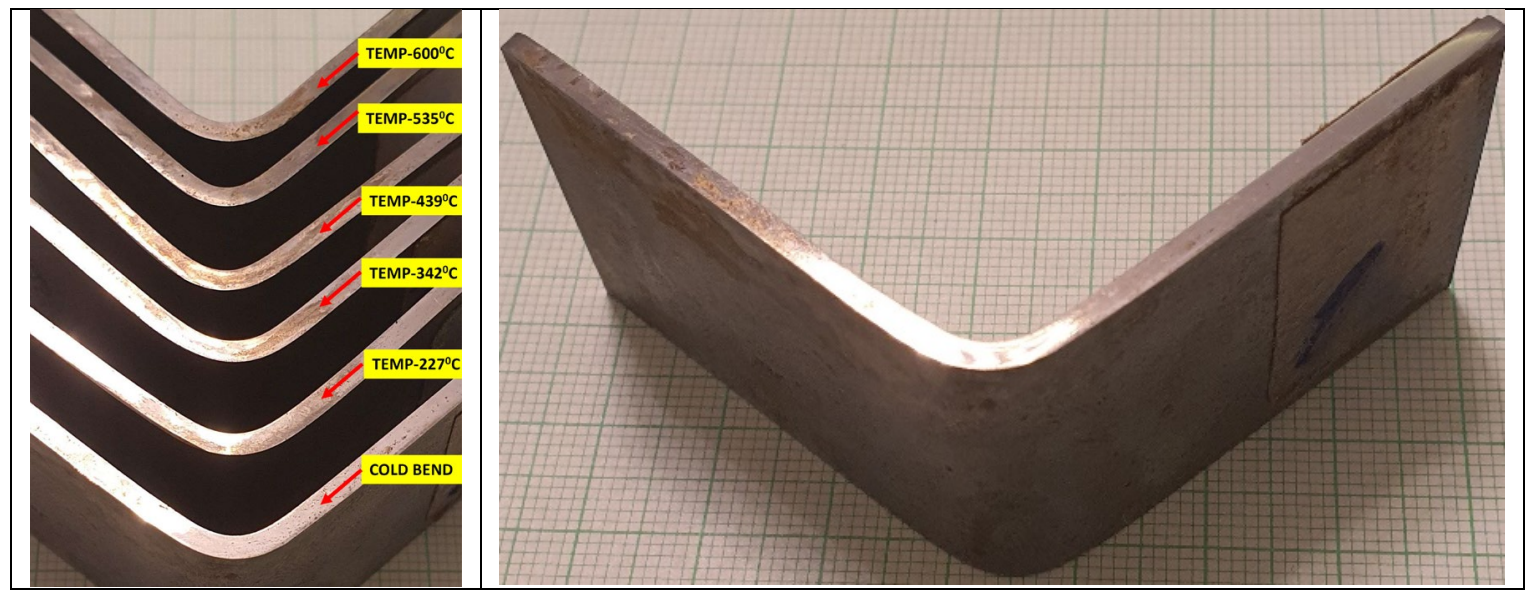

Figure 5: Bended Specimens

\section{RESULTS AND DISCUSSIONS}

The results of the experimental study are summarized in Table 5. No cracks were visually observed on the specimens. The variation of the temperature gradient with respect to time, the variation of the punch load, and the amount spring back with respect to local heating temperature were discussed below. 
Table 5: Summary of the results

\begin{tabular}{|c|c|c|c|c|c|c|}
\hline Specimen & $\begin{array}{l}\text { Final Bend } \\
\text { Angle }\end{array}$ & $\begin{array}{l}\text { Final Bend } \\
\text { Radius }\end{array}$ & $\begin{array}{c}\text { Final Shape After } \\
\text { Bending }\end{array}$ & $\begin{array}{l}\text { Spring } \\
\text { back }\end{array}$ & $\begin{array}{c}\text { Bending Temperature } \\
\left({ }^{\circ} \mathrm{C}\right)\end{array}$ & Max. Bending Force (N) \\
\hline SC-1 & 97,10 & 9,45 & & 7,1 & 18 & 3512 \\
\hline SC-2 & 96,24 & 7,65 & & 6,24 & 227 & 3041 \\
\hline SC-3 & 93,62 & 6,25 & & 3,62 & 342 & 2138 \\
\hline SC-4 & 92,06 & 6,25 & & 2,06 & 439 & 1785 \\
\hline SC-5 & 89,79 & 5,50 & & $-0,21$ & 535 & 922 \\
\hline SC-6 & 87,96 & 6,25 & & $-2,04$ & 600 & 638 \\
\hline
\end{tabular}

\subsection{TEMPERATURE GRADIENTS}

In Figure 6, the temperature gradients on the specimen that was measured by using the thermal camera during bending are shown. Three zones of temperature gradient are defined in the figure. The cooling curves of the three zones are also given in Figure 7 and Figure 8 for initial heating temperatures of $227^{\circ} \mathrm{C}$ - and $342^{\circ} \mathrm{C}$, respectively.

As seen from the figures, the cooling rates are higher for higher initial temperatures as expected and zone 1 that is the inner of the thickness cools later than outer zones. Keep in mind that the die and punch are both in ambient temperature.
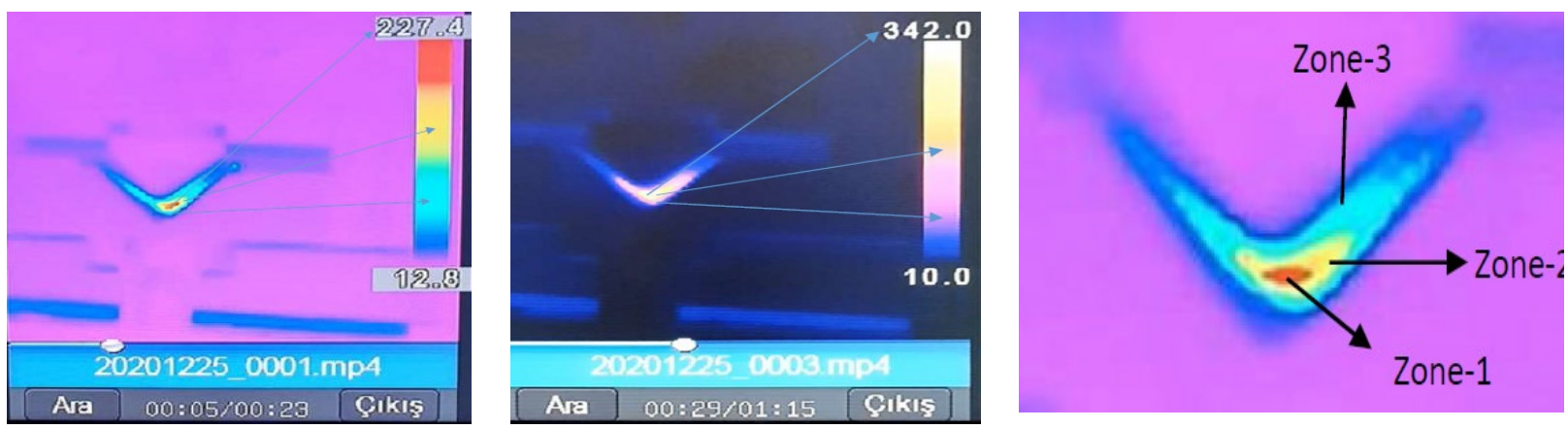

Figure 6: Temperature gradients recorded by thermal camera 


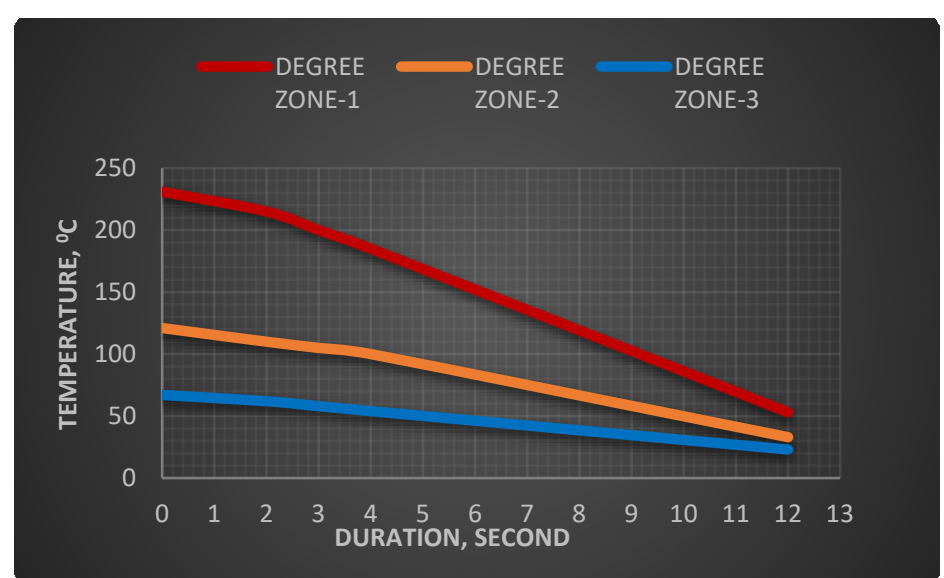

Figure 7: Cooling curves on the bending line from $227^{\circ} \mathrm{C}$

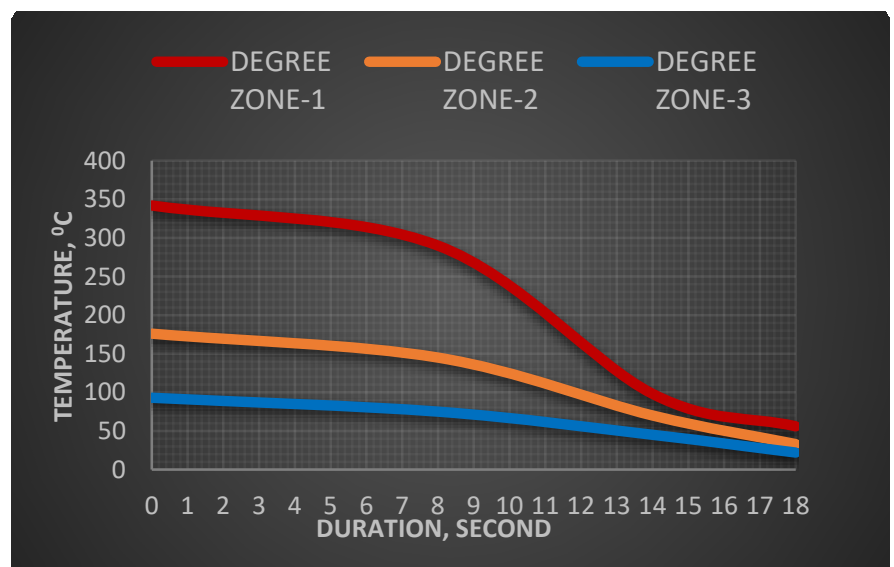

Figure 8: Cooling curves on the bending line from $342^{\circ} \mathrm{C}$

\subsection{PUNCH LOADS}

The load-stroke diagram of the SC-1 specimen set is plotted using the load cell and punch position measurements and given in Figure 9. The curve shows similar trends to the typical bending process and has a maximum punch load of $3512 \mathrm{~N}$. Figure 10 shows the variation of maximum punch loads with respect to local heating temperature. The maximum punch load decreases with temperature due to softening effect.

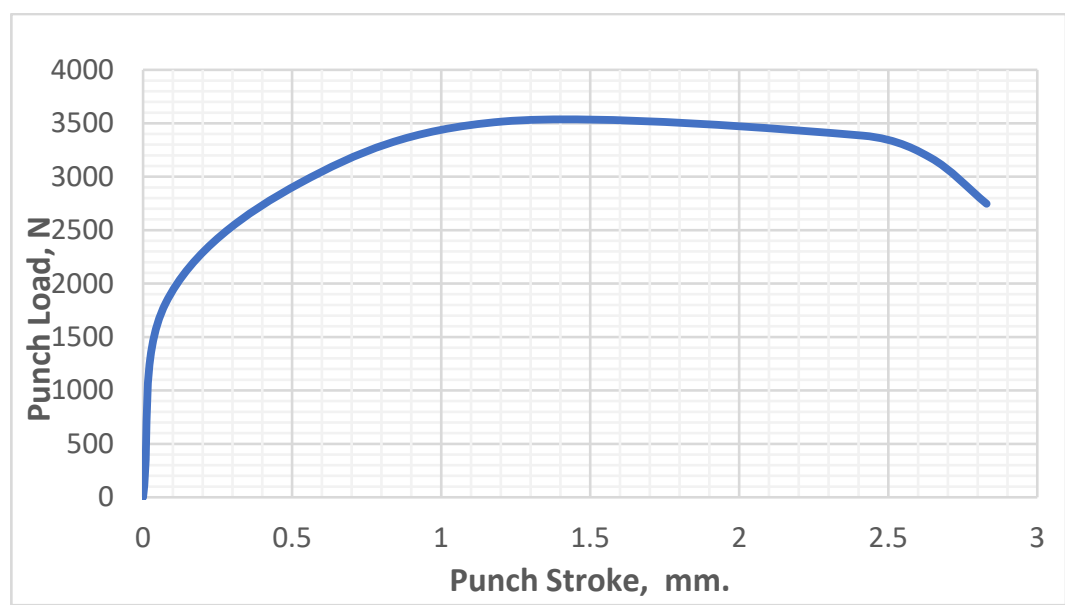

Figure 9: Punch load-stroke diagram for SC-1 specimens 


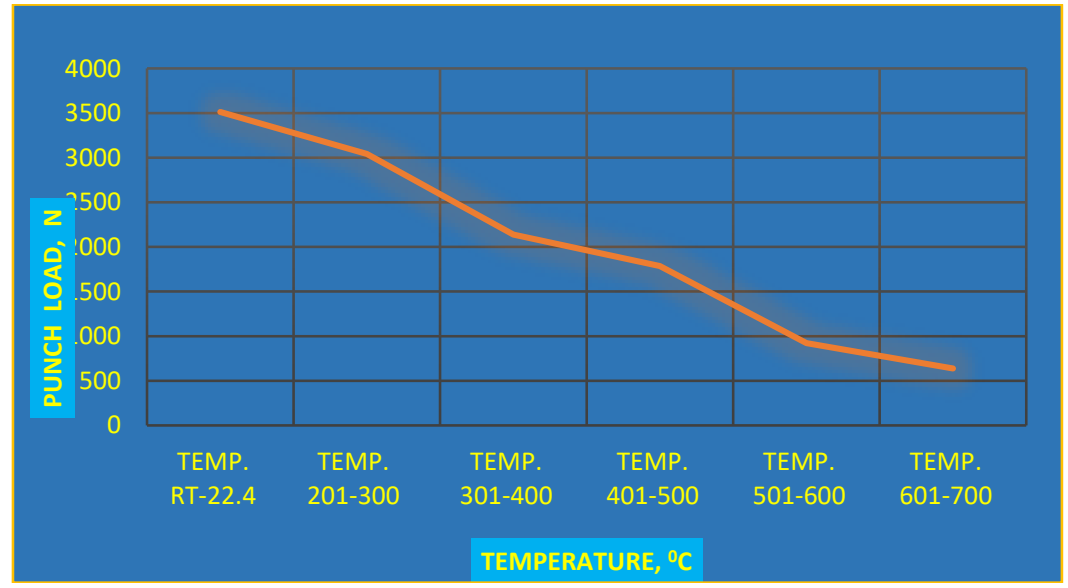

Figure 10: Variation of the maximum punch loads with respect to heating temperatures.

\subsection{SPRINGBACK}

The final bend angles of the specimens were measured by 3D CMM and the deviations from 90 degrees were calculated. Figure 11 shows the variation of the spring back angle with respect to bending temperature. The amount of spring back is decreasing with the bending temperature and around $500^{\circ} \mathrm{C}$ almost no spring-back was measured. Negative spring back (spring-go) was observed for the bending temperatures higher than $500^{\circ} \mathrm{C}$.

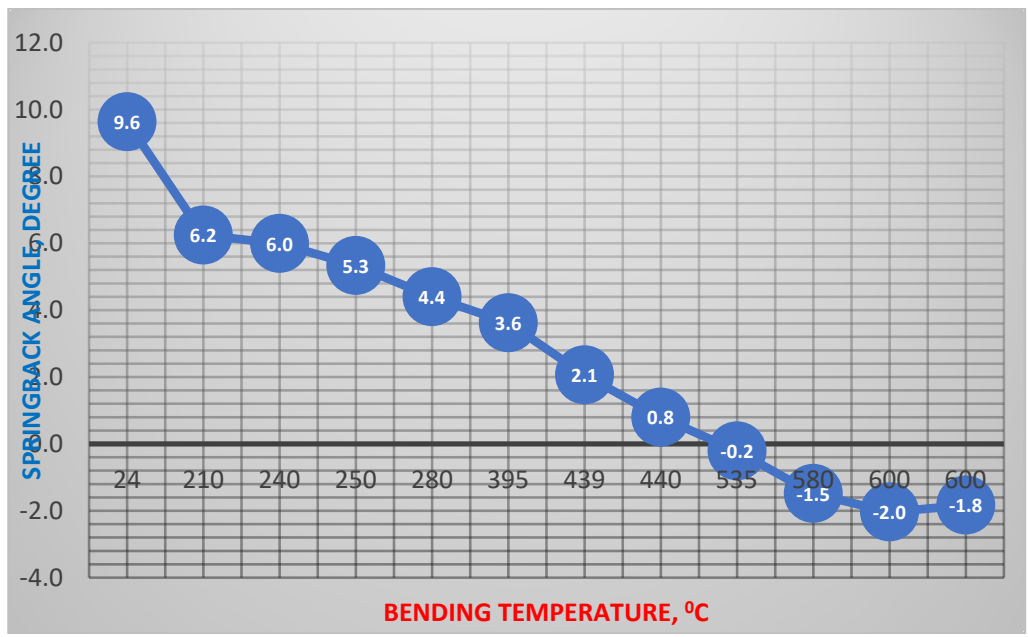

Figure 11: The variation of the springback angle with respect to bending temperature.

\section{CONCLUSIONS}

The experimental study was carried out on a $2 \mathrm{~mm}$ thick Docol $1500 \mathrm{M}$ steel at various temperatures by using a speed-controlled servo press machine. The bending regions of the specimens were locally heated to $200,300,400$, 500 , and $600 \mathrm{oC}$ by using a high-frequency induction heating device. From the experimental results the followings can be concluded:

- No crack was visually observed on the specimens after V-bending

- The cooling rates are higher for higher initial temperatures and zone 1 that is the inner of the thickness cools later than outer zones.

- The maximum punch load decreases with temperature due to softening effect.

- The amount of spring back is decreasing with the bending temperature and around $500^{\circ} \mathrm{C}$ almost no springback was measured. Negative spring back (spring-go) was observed for the bending temperatures higher than $500^{\circ} \mathrm{C}$. 


\section{SOURCES OF FUNDING}

This research received no specific grant from any funding agency in the public, commercial, or not-for-profit sectors.

\section{CONFLICT OF INTEREST}

The author have declared that no competing interests exist.

\section{ACKNOWLEDGMENT}

None.

\section{REFERENCES}

[1] Pablo M. Romero, Germán J. Rodríguez, Jorge L. Arias, and Joaquín Vázquez. (2006). Spring-back control in laser assisted mechanical forming of dual phase steels, Laser Materials Processing Conference, pp. 841-850. (https://doi.org/10.2351/1.5060926)

[2] Ozturk, F., Toros, S., Kilic, S. (2009). Journal of iron and steel research. International, 16(6), pp. 41-46. (https://doi.org/10.1016/S1006-706X(14)60191-6)

[3] Eun-Ho Lee, June-Sun Hwang, Chang-Whan Lee, Dong-Yol Yang, Woo-Ho Yang. (2014). A local heating method by near-infrared rays for forming of non-quenchable advanced high-strength steels, Journal of Materials Processing Technology 214, pp. 784- 793. (https://doi.org/10.1016/j.jmatprotec.2013.11.023)

[4] Yuki Nakagawa, Ken-ichiro Mori, Tomoyoshi Maeno. (2018). Springback-free mechanism in hot stamping of ultra-high-strength steel parts and deformation behavior and quenchability for thin sheet, Int J Adv Manuf Technol 95, pp.459-467. (https://doi.org/10.1007/s00170-017-1203-3)

[5] J. Yanagimotol, K. Oyamada. (2005). Springback of High-Strength Steel after Hot and Warm Sheet Forming, CIRP Annals Volume 54, Issue 1, Pages 213-216. (https://doi.org/10.1016/S0007-8506(07)60086-9)

[6] Myoung-Gyu Lee, Sung-Joon Kim, Heung Nam Han. (2009). Finite element investigations for the role of transformation plasticity on springback in hot press forming process, Computational Materials Science 47, pp.556-567. (DOI: 10.1016/j.commatsci.2009.09.024)

[7] Andreas Weisheit, (2009). Local laser heat treatment of ultra-high strength steels to improve formability, Production Engineering 3(4), pp.347-351. (DOI: 10.1007/s11740-009-0186-9)

[8] Larsson, Linus. (2005). Warm Sheet Metal Forming with Localized In-Tool Induction Heating, Coden: LUTMDN/(TMMV-1060), pp.1-84 (Warm Sheet Metal Forming with Localized In-Tool Induction Heating.)

[9] Lei Deng, Xinyun Wang, Junsong Jin, Liangjun Xia. (2020). Springback and Hardness of Aluminum Alloy Sheet Part Manufactured by Warm Forming Process Using Non-Isothermal Dies, International Conference on the Technology of Plasticity, pp. 17-22. (DOI: 10.1016/j.proeng.2017.10.1013)

[10] Fuh-Kuo Chen., Shi Wei Liu. (2013) Die Compensation Design for Stamping A High Strength Automotive Bumper Inner, Advanced Materials Research, pp. 712-715:796-799. (https://doi.org/10.4028/www.scientific.net/AMR.712-715.796). 